\title{
一般演題 8
}

\section{新しい酸素テントについて}

酸素テントは, 酸素療法の装置として, 広く 利用されているが，使用条件としては外気の温 度・湿度条件の如何にかかわらず，患者に対し て常に最適な環境下で酸素療法の行なえること が必要である。この条件を満足させるために従 来の装置を更に改良して, 完全自動温度湿度調 節装置を備えた酸素テント（写真 1）を完成し たので，ここにその概略を報告する.

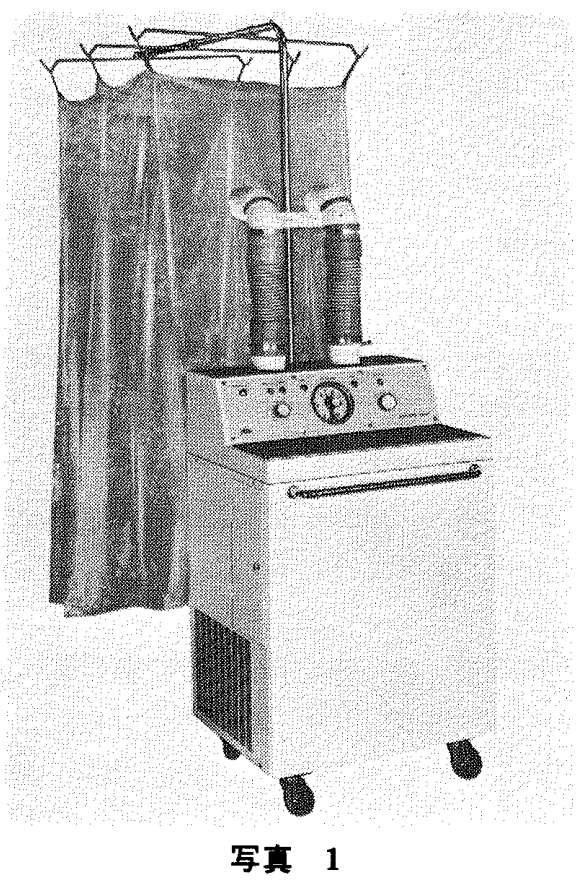

\section{1. 動作原理}

本装置は空気調節装置を備えた一種の閉鎖循 環装置で, ベッド上の患者の上半身をフードで 蔽い, フード内の空気をダクトを通してファン により循環せしめ，ダクト入口の空気の温度お よび湿度を監視して, 冷却器・加熱器および加 *東芝放射線株式会社.
用隆*

湿器の電源を各々リレーにて断続して, フード 内の空気を所要の温度・湿度に自動的に調節す ると共に, 酸素をボンべから流量計で監視しつ つ補給してフード内を高酸素濃度に保持するよ らになっている.

\section{2. 設計上の要点と構造}

本装置の設計上の要点としては

（1）温度および湿度の調節が容易にできる

（2）運転時の騒音・振動が少ない

(3) 操作が簡単である

（4）長期間の使用に耐えうる

等が考慮されている。

装置の構造は, 図 1 の装置概要図に示すよう に, 冷却器・加熱器・加湿器およびファンが同 一ダクト内に設置されている.この泠却器・加

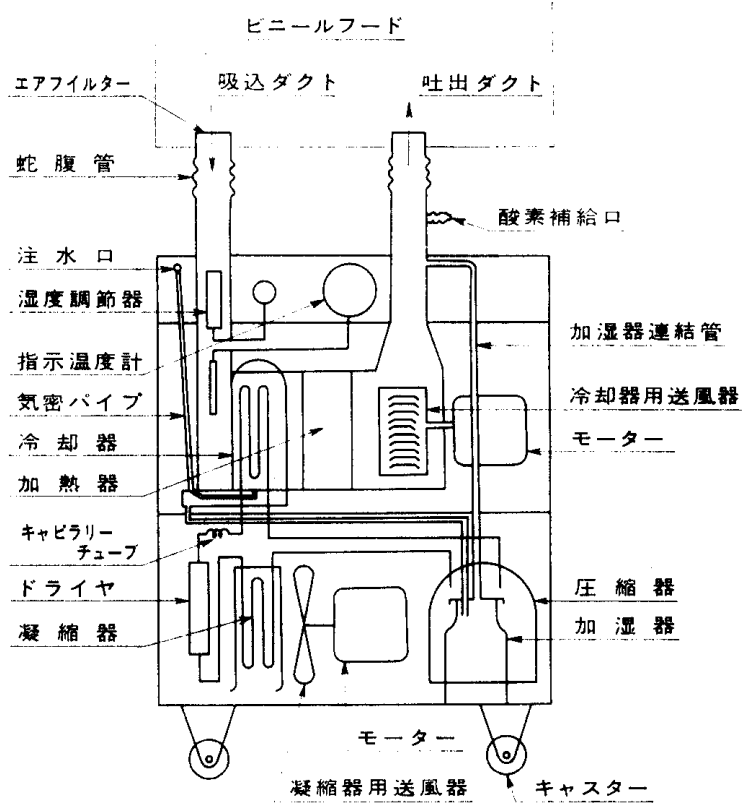

図 1 


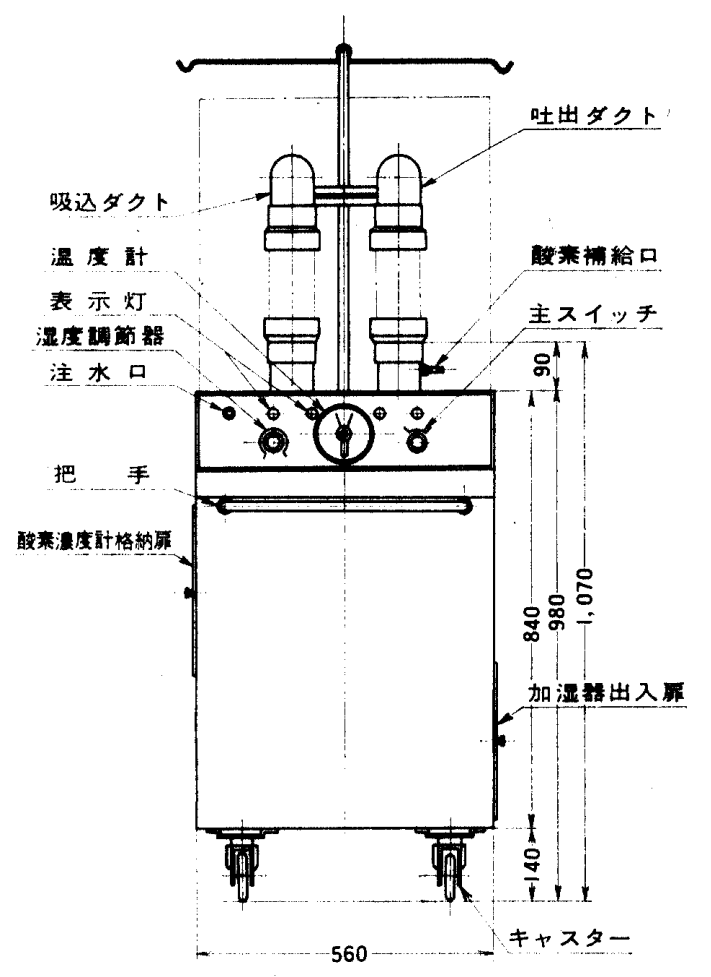

図 2
熱器は長期間の使用に耐えうるよう全密閉式を 採用している。 また，加湿器には高湿度が容易 に得られ，雑音の発生のない速熱筒付電極式を 採用し, 凝結水は加湿器に導かれるようになっ ているので, 排水の必要がない.

吸込・吐出ダクト部は，フード支柱により吊 られたフード内に接続されていて，吸込ダクト 内には除歴フィルター, 温度および湿度調節器 が，また，吐出ダクト側には酸素補給に・加湿

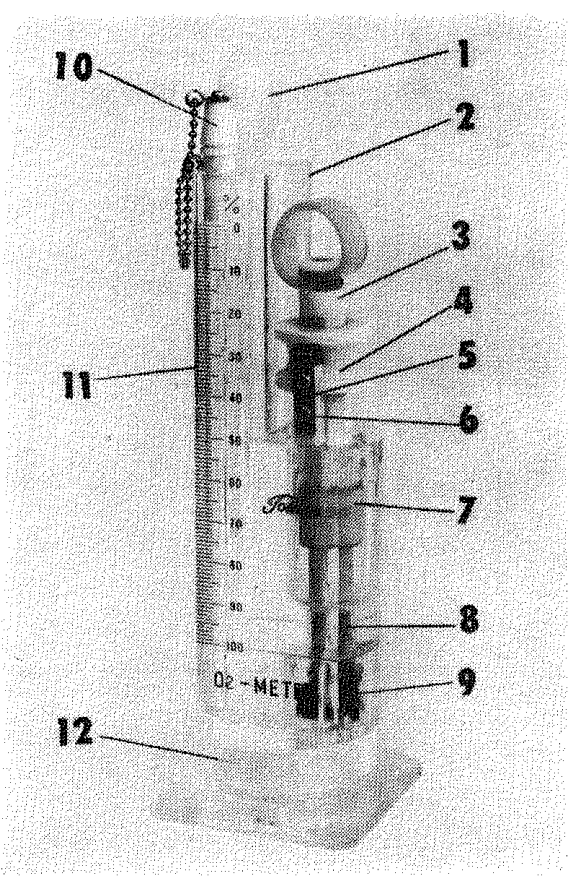

写真 $21 \cdots$ スポイト $2 \cdots$ 本体 $3 \cdots$ ピスト ン・ $4 \cdots$ シリンダ(試料採集器) 5 ・ ストッパ 6 ‥調整ネジ $7 \cdots$ 挿入 ت゙ム $8 \cdots$ 嵌合部 $9 \cdots$ 反応室 $10 \cdots$ 栓 $11 \cdots$ 水位計 $12 \cdots$ 底

ロが備えてある.除塵フィルターは簡単に取り 外し，清掃・消毒することができる。これらの 調節器は図 2 の前面パネル上のツマミにより操 作および表示灯による運転の監視ができる.

フード内の酸素濃度の測定には，写真 2 の酸 素濃度計を使用して測定を行なう。この酸素濃 度計は一定量の被測定空気を反応室に送入し， 酸素を試薬に吸収させ，この体積の減少度を水 位計で指示するもので，装置本体に格納できる

ようになっている.

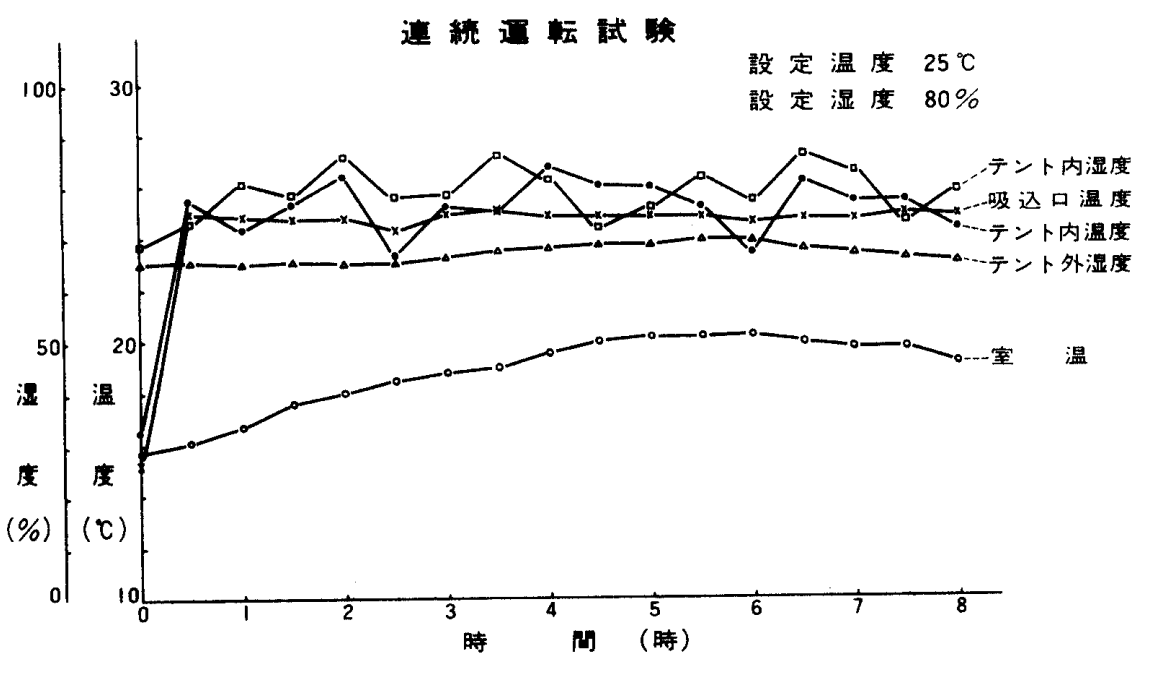

图 3

\section{3. 温度と湿度の関係}

湿った空気を冷却すると 相対湿度は増加して飽和湿 り空気となり，さらに冷却 すると水蒸気は凝結して水 滴となり放出され絶体湿度 は低下し，冷却部で除湿が 行なわれる。この時温度の 設定条件によっては，冷却 部に結霜ができる場合があ るので, 冷却器には結霜を 防止するための自動霜取装 
置を取り付け冷却能力の低下を防止している.

図 3 は連続運転を行なった実験結果で，運転 開始後約 30 分以内にフード内の温度・湿度共に 設定値になり，変動も少なく良好な結果が得ら れた。 また，振動・騒音等も少なくすることが できた.

以上新しく改良を加えた酸素テントについて 述べたが，従来の装置に比べ，ょり使いやす く, また患者に対して, 快適な環境下で酸素療 法ができるように考慮した装置である.

質 問

\section{東医歯大 手術部 古 橋 正 吉}

1）酸素テントに付属させている化学分析 $\mathrm{O}_{2}$ 濃度計㹥誤差が大きく余り利用されていな い. 電磁式 $\mathrm{O}_{2}$ 濃度測定計の方が理論的にも実 際的にも正確なのでこれ付偊させる必要はな いくらいに思う.

2）酸素テントのデスクに使用のポイントを 標示するようにしてほしい.テントフードには 火気厳禁の標示もほしい.

3）湿度の標示に確信があるんでしょうか。 テントの湿度コントロールは極めて難しい問題 です.

间 答

\section{東芝放射線 宮 田隆}

ご指摘の点については，今後の製品に取り入 れていきたい。

質 問

\section{医器研 早 川 真夫}

附属の $\mathrm{O}_{2}$ 濃度計の精度を上げるため何等か の処置がとられているか.この型の濃度計は大 きな誤差が出やすいと思います.

湿度自動調節の検体にナイロンリボンを用い てあるが，この種の物で $5 \%$ 内外とし，不精確 さは調節できないと思うが，その点どうなって いますか。
回 答

\section{東芝放射線 宮 田隆}

酸素濃度計の試料採集器のリークがないよう にした。

テント内の湿度自動調節は実験では土 $5 \%$ 以 内の結果が得られた.

質 問

\section{泉工医科工業 若 井 秀 治}

湿度自動調節の範囲はどれ位であるか。また 湿度調節は70\%以上の場合で必要であると思い ますが，その点をお聞きします。

回 答

\section{東芝放射線 宮 田隆}

40７0\%以上となっていますが，80\%までは 調節が可能です.

質 問

\section{泉工医科工業 井 上 政 昭}

1. 湿度コントロールの湿度検出は何をつかって いるか。

2. 酸素テント内で場所によって酸素濃度はどれ くらい差があるか.

回 答

$$
\begin{gathered}
\text { 東芝放射線 宮 田 隆 } \\
\text { ナイロンリボン型を使っている.テント内の }
\end{gathered}
$$
酸素濃度の測定は患者の鼻の近くを測定してい るが，他の所でもあまり差はない．

追 加

\section{泉工医科工業 青 木 利三 郎}

われわれも酸素テントの開発を行なってお り，とくにビニールテントは二重の袋状にして その中に空気を入れますと，外気との温度差が 大きくとれより効率よく使用できる. 